\title{
Parental Involvement Strategies Vis-à-Vis Academic Performance of Junior High School Students in Mathematics
}

\author{
Avelina M. Aquino, Cecilia J. Sabio, Florinda G. Vigonte, and Nerinissa R. De Leon
}

\begin{abstract}
This study covered 237 students of Angat National High School in Taboc, Angat, Bulacan - Philippines particularly the students of Junior High School department for the 2nd Grading Period of the Academic Year 2017-2018. This was delimited to 40 percent sample randomly chosen from the population of 581junior high school, and the 237 parents of the total student respondents. Descriptive correlational method of research was utilized in this study with questionnaire as the main instrument for gathering data. Academic performance was quantified using the grade point average of students in Mathematics. 23 students or 9.7 percent were in the "advanced proficiency level in Mathematics. Generally, the overall performance of the students in Mathematics may be described as "approaching proficiency. The results of analysis of variance revealed and F-ratio of .990 with associated probability of $p=.422$ which indicates that the parental involvement strategies like mentoring, parental involvement initiatives, awarding scheme and achievement recognition affect the academic performance of the students in Mathematics but not to a significant extent. Since the associated probabilities of the coefficients were found to be higher than the significance level set at $\mathbf{. 0 5}$, it was found to be non-significant. The null hypothesis is sustained. Conclusions were drawn and recommendations were offered.
\end{abstract}

Index Terms-Academic performance, junior high school, mathematics, parental involvement.

\section{INTRODUCTION}

Academic performance has gained significant attention for past researches for it plays an influential role in bringing into being the finest quality alumnae who will become future leaders and manpower of a country (Singh,2016) [1]. Empirical studies are carried out all over the world to investigate factors enhancing the students' academic performance in Mathematics primarily because these are two of the most challenging subjects in school. Parental involvement in school activities has always been a major concern of the teachers in teaching -learning process. Many parents once they enrolled their children were passive in their child's education. According to Mathipa (2014) [2], the two key elements that work together to make up the concept of parental involvement are the level of commitment to parental support and the level of parental activity and participation.

Manuscript received January 30, 2019; revised August 3, 2019.

Avelina M. Aquino is with the Bulacan State University (BulSU), Pulilan Extension, Pulilan, Bulacan, Philippines (e-mail: avejao17@gmail.com).

Cecilia J. Sabio, Florinda G. Vigonte, and Nerinissa R. De Leon were with De La Salle Araneta University, BulSU Bustos Campus, Bulacan, Philippines, and DepEd Bulacan, Philippines (e-mail: vpcfjs@gmail.com, florvigonte@yahoo.com, nissayen15@gmail.com).
Angat National High School is not spared from such situation. Students and parents have linked different parental involvement strategies associated with academic achievement. It is therefore necessary that students be made aware of these strategies in order to help them become academic achievers. These strategies include strategies such as mentoring, initiatives, awarding scheme and achievement recognition.

It is in this light that the researchers aimed at assessing the parental involvement strategies associated with students' academic achievement that may be used by teachers as basis for intervention program.

This study used the IV-DV model as depicted in Fig.1 Conceptual framework.

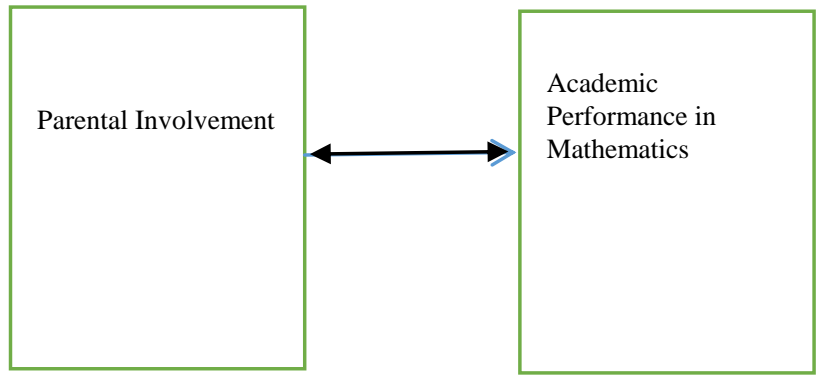

Fig. 1. Conceptual framework of the study.

\section{A. Statement of the Problem}

The major purpose of the researchers was to assess how parental involvement could enhance the academic performance of Junior High School students in Mathematics.

Specifically, the researcher aimed to answer the following questions:

1) What parental involvement strategies were utilized by parents in enhancing students' academic performance in Mathematics in terms of:

1.1 Mentoring Strategies;

1.2 Parental Involvement Initiatives;

1.3 Awarding Scheme Strategies; and

1.4 Achievement Recognition Strategies.

2) What is the profile of the students' Academic Performance in Mathematics?

3) Does the extent of parental involvement strategies affect students' academic performance?

4) What are the common problems and issues encountered by the teachers regarding the involvement of the parents?

B. Hypothesis of the Study

The researchers hypothesized that:

Ho The parental involvement strategies do not 
significantly affect students' academic achievement in Mathematics.

\section{METHOD}

\section{A. Research Design}

The descriptive correlational method of research was utilized in this study to determine if there is a relationship between the two variables (Padgett, 2016). Research interest was to assess the effect of the extent of parental involvement strategies on students' academic performance in Mathematics.

\section{B. Participants}

The participants of the study were 237 Junior High School students and their parents of Angat National High School in Taboc, Angat, Bulacan for the 2nd Grading Period of the Academic Year 2017-2018.

\section{Research Instrument}

The researcher adopted the parental involvement strategy questionnaire developed by Abulon (2016) [3] of the Philippine Normal University. The second set of instrument was a questionnaire checklist intended for the teachers which deals with their common problems encountered in involving parents in social activities, and in providing mentoring activities to their children.

\section{Data Gathering Procedure}

The data gathered were processed by computer system using the Statistical Packages for Social Sciences (SPSS).

The parental involvement strategies utilized by parents in enhancing the students' performance were assessed using a five - point Likert Scale interpreted as follows.

Scale Range Verbal interpretation 5

5.00 Always

$4 \quad 3.50-4.49 \quad$ Frequently

$3 \quad 2.50-3.49 \quad$ Sometimes

$2 \quad 1.50-2.49 \quad$ Rarely

$$
1 \quad 1.00-1.49 \quad \text { Never }
$$

The profile of students' academic performance was examined using frequency counts and percent interpreted as follows:

$\begin{array}{ll}\text { Scores } & \text { Descriptive Equivalent } \\ 90 \% \text { and above } & \text { Advanced } \\ 85-89 \% & \text { Proficient } \\ 80-84 \% & \text { Approaching Proficiency } \\ 75-79 \% & \text { Developing } \\ 74 \% \text { and below } & \text { Beginning }\end{array}$

The extent of parental involvement strategies on students' academic performance was analyzed using correlation and regression analysis.

The common problems and issues encountered by teachers was analyzed using frequency counts and ranking system.

\section{RESULTS AND DISCUSSION}

\section{A. Parental Involvement Strategies Utilized by Parents in Enhancing Students' Academic Performance in Mathematics}

Different parental involvement strategies were utilized by parents in enhancing the academic performance of the students in Mathematics. This includes mentoring strategies, parental involvement initiatives, awarding scheme strategies and achievement recognition strategies.

\section{B. Mentoring Strategies}

It can be gleaned from Table I that "reminding your child of the importance of going to school." and "conversing with your child about what happened in school after his/her class before going to sleep got the highest mean of 4.15 and 3.54 respectively with a descriptive equivalent of Frequently, "sharing stories or books to your child at home." got the lowest mean of 2.23 with descriptive equivalent of rarely. The overall mean for mentoring strategies is 3.13 with a descriptive equivalent of sometimes. The data can be interpreted that mentoring like assessing children in doing homework, tutoring and sharing stories is more effective in the early age. Students in the high school level prefer reminders and encouragement from parents over working directly with them. They simply wish to maintain their connection to their parents. They seek emotional intimacy with their parents and express a desire to satisfy parents' expectations. This finding was supported by the study of Crosby et.al (2012) [4] that mentoring tends to be greatest with young children and then taper off as children get older.

The grand mean of 3.13 indicated that mentoring strategies were sometimes utilized by the parent respondents in enhancing their academic performance in Mathematics.

TABLE I: PARENTAL INVOLVEMENT IN TERMS OF MENTORING STRATEGIES

\begin{tabular}{|c|c|c|}
\hline Indicators & Mean & Interpretation \\
\hline $\begin{array}{l}\text { 1.Assisting your child in dong their } \\
\text { assignments. }\end{array}$ & 2.97 & Sometimes \\
\hline $\begin{array}{l}\text { 2.Tutoring children in subjects they find } \\
\text { difficult. }\end{array}$ & 2.80 & Sometimes \\
\hline $\begin{array}{l}\text { 3.Sharing stories or books to your child at } \\
\text { home. }\end{array}$ & 2.23 & Rarely \\
\hline $\begin{array}{l}\text { 4.Reminding your child the importance of } \\
\text { going to school }\end{array}$ & 4.15 & Frequently \\
\hline $\begin{array}{l}\text { 5.Conversing with your child about what } \\
\text { happened in school after his/her class before } \\
\text { going to sleep. }\end{array}$ & 3.54 & Frequently \\
\hline Average & 3.13 & Sometimes \\
\hline
\end{tabular}

\section{Parental Involvement Strategies}

Table II reveals that only "initiating to have meetings with other parents for an activity that would benefit the children." got a mean of 2.29 with a descriptive equivalent of rarely utilized. The rest of the indicators got a mean of 3.24, 3.42, 2.55 and 2.60 respectively with a descriptive equivalent of sometimes utilized. Overall, parental involvement strategies got an average of 2.82 meaning parental involvement strategies is sometimes observed by the parent respondents. The result further implies that teacher-parent/teacher-school relationship is greater than parent-parent. Parents rarely initiates parent to parent collaboration leading to their 
children's academic achievement.

TABLE II: PARENTAL INVOLVEMENT IN TERMS OF PARENTAL INVOLVEMENT STRATEGIES

\begin{tabular}{|c|c|c|}
\hline Indicators & Mean & Interpretation \\
\hline $\begin{array}{l}\text { 1. Participating in school programs } \\
\text { when invited by the school (e.g. } \\
\text { family day) }\end{array}$ & 3.24 & Sometimes \\
\hline $\begin{array}{l}\text { 2. Attending regular progress } \\
\text { meetings with teachers (e.g. } \\
\text { showing or report card) }\end{array}$ & 3.42 & Sometimes \\
\hline $\begin{array}{l}\text { 3. Initiating to have meetings with } \\
\text { other parents for an activity that } \\
\text { would benefit the children. }\end{array}$ & 2.29 & Rarely \\
\hline $\begin{array}{l}\text { 4. Doing volunteer work for the } \\
\text { school (e.g. cleaning drive, } \\
\text { bringing refreshments during } \\
\text { activities, sharing stories to your } \\
\text { child's class). }\end{array}$ & 2.55 & Sometimes \\
\hline $\begin{array}{l}\text { 5. Initiating small talks with teachers } \\
\text { about the progress of your child } \\
\text { in school. }\end{array}$ & 2.60 & Sometimes \\
\hline Average & 2.82 & Sometimes \\
\hline
\end{tabular}

\section{Awarding Scheme Strategies}

Table III clearly shows evidence that awarding scheme strategy in terms of "rewarding with letter of appreciation" was always used as shown by the computed mean value of 4.87. the other four indictors obtained mean values ranging from 2.70 to 2.96 with a descriptive equivalent of Sometimes. The result clearly supports the claim of Deci (2012) [5] that intrinsic motivation is more important than extrinsic motivation. It was further strengthened by the Self-determination theory of Carlos and others (2015) [6] that extrinsic motivation should not be encouraged because it might harm students' intrinsic motivation and that the approach might be ineffective in the short run and detrimental in the long run.

TABLE III: PARENTAL INVOLVEMENT IN TERMS OF AWARDING SCHEME STRATEGIES

\begin{tabular}{|c|c|c|}
\hline Indicators & Mean & Interpretation \\
\hline $\begin{array}{l}\text { 1. Giving monetary rewards for } \\
\text { good performance of } \\
\text { children. }\end{array}$ & 2.75 & Sometimes \\
\hline $\begin{array}{l}\text { 2. Extending non-monetary } \\
\text { rewards like educational } \\
\text { trip travels for outstanding } \\
\text { performance in school. }\end{array}$ & 2.96 & Sometimes \\
\hline $\begin{array}{l}\text { 3. Granting independence and } \\
\text { freedom on study methods. }\end{array}$ & 2.89 & Sometimes \\
\hline $\begin{array}{l}\text { 4. Rewarding with letter of } \\
\text { appreciation. }\end{array}$ & 4.87 & Always \\
\hline 5. Handling out a tangible gift. & 2.67 & Sometimes \\
\hline
\end{tabular}

\begin{tabular}{lcc}
\hline Average & 3.23 & Sometimes \\
\hline
\end{tabular}

\section{E. Achievement Recognition Strategies}

The data in Table IV reflect that achievements recognition strategies were sometimes used by the parents as shown by the obtained mean value of 2.71. All the first four indicators are descriptively interpreted as sometimes utilized except for the fifth "displaying congratulatory messages (like tarps) for outstanding achievements of the children." which got a mean of 1.36 interpreted as rarely utilized. This means among the parent respondents recognize children's achievement by displaying in public their congratulatory messages. The Filipinos according to Andrea Chloe Wong (2012) [7] are renowned all over the world for remarkable qualities, often downplayed or overlooked, but which nonetheless brings pride to the country. Thus, from the result of this study, it can be inferred that recognizing students' achievement may help students become challenged and responsive resulting to improved academic achievement in Mathematics.

TABLE IV: PARENTAL INVOLVEMENT IN TERMS OF AWARDING RECOGNITION STRATEGIES

\begin{tabular}{|c|c|c|}
\hline Indicators & Mean & Interpretation \\
\hline $\begin{array}{l}\text { 1. Recognizing good } \\
\text { performance of children in } \\
\text { government achievement } \\
\text { test. }\end{array}$ & 3.36 & Sometimes \\
\hline $\begin{array}{l}\text { 2. Giving of recognition to } \\
\text { meritorious } \\
\text { accomplishment of the } \\
\text { child. }\end{array}$ & 3.23 & Sometimes \\
\hline $\begin{array}{l}\text { 3. Holding simple events } \\
\text { recognizing curricular and } \\
\text { co-curricular achievements } \\
\text { of child. }\end{array}$ & 2.74 & Sometimes \\
\hline $\begin{array}{l}\text { 4. Publisizing achievement of } \\
\text { children on social media } \\
\text { like FB, IG and Tweeter. }\end{array}$ & 2.37 & Sometimes \\
\hline $\begin{array}{l}\text { 5. Displaying congratulatory } \\
\text { messages (like tarps) for } \\
\text { outstanding achievements } \\
\text { of the children. }\end{array}$ & 1.86 & Rarely \\
\hline Average & 2.71 & Sometimes \\
\hline
\end{tabular}

\section{F. Profile of the Academic Performance of Students in Mathematics}

Academic Performance refers to the extent to which students have achieved their short or long term goals. As used in the study, educational performance was quantified using the grade point average of students in Mathematics. Table V presents the data.

The data show that 23 students or 9.7 percent were in the "advanced proficiency level in Mathematics. Only 3 students or 1.2 percent were at the beginning level ". A total of 44 students or 18.6 percent were on the developing level of proficiency. The rest have reached the "approaching proficiency level", (24.5 percent) level of performance in Mathematics. In general, the overall performance of the students in Mathematics may be described as "approaching proficiency ".

Parents too have very important role to play in enhancing the academic performance of students in Mathematics. The extent to which parents involve themselves through mentoring strategies, parental involvement initiative strategies, awarding scheme strategies, and achievement 
recognition strategies may contribute significantly in the overall academic performance of their children.

TABLE V: ACADEMic PeRformance of Students in Mathematics

\begin{tabular}{|c|c|c|c|c|c|c|c|c|c|c|c|c|c|}
\hline \multirow{3}{*}{$\begin{array}{l}\text { Grade } \\
\text { Lerel }\end{array}$} & \multicolumn{13}{|c|}{ Academic Performance } \\
\hline & \multicolumn{2}{|c|}{ Advance } & \multicolumn{2}{|c|}{ Proficiency } & \multicolumn{2}{|c|}{$\begin{array}{l}\text { Approaching } \\
\text { Proficiency }\end{array}$} & \multicolumn{2}{|c|}{$\begin{array}{l}\text { Develo- } \\
\text { ping }\end{array}$} & \multicolumn{2}{|c|}{ Beginning } & \multirow[t]{2}{*}{ Total } & \multirow[t]{2}{*}{ Mean } & \multirow[t]{2}{*}{$\begin{array}{l}\text { Descriptive } \\
\text { Equivalent }\end{array}$} \\
\hline & $\mathbf{F}$ & $\%$ & $\mathbf{F}$ & $\%$ & $\mathbf{F}$ & $\%$ & $\mathbf{F}$ & $\%$ & $\mathbf{F}$ & $\%$ & & & \\
\hline 10 & 4 & 7.5 & 21 & 39.6 & 20 & 37.7 & 8 & 15.1 & 0 & 0 & 53 & 3.32 & AP \\
\hline 9 & 3 & 6.8 & 26 & 60.5 & 11 & 25.6 & 3 & 6.9 & 0 & 0 & 43 & 3.67 & $\mathbf{P}$ \\
\hline 8 & 10 & 19.2 & 21 & 40.4 & 14 & 26.9 & 7 & 13.5 & 01 & 0 & 52 & 3.65 & $\mathbf{P}$ \\
\hline 7 & 6 & 6.7 & 41 & 46.1 & 14 & 14.6 & 26 & 29.2 & 3 & 3.4 & 89 & 3.23 & AP \\
\hline $\mathbf{T}$ & 23 & 9.7 & 109 & 46.0 & 58 & 24.5 & 44 & $\begin{array}{l}18.6 \\
\end{array}$ & 3 & 1.2 & 237 & 3.47 & AP \\
\hline
\end{tabular}

\section{G. Extent of How Parental Involvement Strategies Affect} Students' Academic Performance

In studying the effects of parental involvement strategies on students' academic performance, the following hypothesis was tested: "parental Involvement strategies do not exert significant influence on students' academic performance."

Results of the regression analysis presented in Table VII revealed that the four parental involvement strategies employed by parents influence the academic performance of students in Mathematics in varying extent. This was shown by the obtained non zero B coefficients. A closer look at the obtained coefficients, one could glean that the achievement recognition and awarding scheme strategies employed by parents registered greater effects than mentoring and parental involvement initiatives. Achievement recognition strategies recorded a B coefficient of 1.66 which means that for every unit implementation of achievement recognition strategies, performance of students can be expected to improve by 1.66. However, the associated probabilities of obtained coefficients were all greater than the alpha set of .05 which indicates that while the parental involvement strategies produced positive effect why were not to a significant extent.

Table VI shows the results of the analysis of variance on the effects of the parental involvement strategies on the academic performance of the students. The data revealed an $\mathrm{F}$ ratio of .654 , with an associated probability equal to .627 . Results of the ANOVA showed that even the combined effects of the four parental involvement strategies did not produce significant effects on the academic performance of students.

TABLE VI: ANALYSIS OF VARIANCE ON THE EFFECTS OF PARENTAL INVOLVEMENT STRATEGIES ON ACADEMIC PERFORMANCE IN

\begin{tabular}{llllll}
\multicolumn{7}{c}{ MATHEMATICS } \\
\hline Model & $\begin{array}{l}\text { Sum of } \\
\text { Squares }\end{array}$ & Df & $\begin{array}{l}\text { Mean } \\
\text { Square }\end{array}$ & F & Sig. \\
\hline 1 Regression & 55.612 & 4 & 13.903 & .654 & $.627^{\text {a }}$ \\
Residual & 977.212 & 46 & 21.244 & & \\
\hline Total & 1032.824 & 50 & & &
\end{tabular}

a. Predictors: (Constant), Achievement, Mentoring, Parental, Awarding

b. Dependent Variable : Mathematics
Table VII presents the results of the regression analysis on the effects of Parental Involvement Strategies on the academic performance of the students in Mathematics.

TABLE VII: REGRESSION ANALYSIS ON THE EFFECTS OF PARENTAL INVOLVEMENT STRATEGIES ON ACADEMIC PERFORMANCE IN MATHEMATICS

\begin{tabular}{|c|c|c|c|c|c|}
\hline \multirow[t]{2}{*}{ Model } & \multicolumn{2}{|c|}{ Unstandardized Coefficients } & & \multirow[t]{2}{*}{$\mathrm{T}$} & \multirow[t]{2}{*}{ Sig. } \\
\hline & B & Std Error & Beta & & \\
\hline 1 (Constant) & 82.147 & 2.993 & & 27.447 & .000 \\
\hline Mentoring & .279 & .837 & .051 & .333 & .740 \\
\hline Parental & .127 & .927 & .024 & .137 & .892 \\
\hline Achievement & 1.118 & .990 & .216 & 1.129 & .265 \\
\hline Awarding & 1.668 & 1.136 & .299 & 1.469 & .149 \\
\hline
\end{tabular}

\section{H. Common Problems and Issues Encountered by the Teachers Regarding the Involvement of the Parents}

Table VIII accounts the common problems and issues encountered by the teachers regarding the involvement of parents in enhancing the academic performance of the students. Apparently, the "inability of parents to give physical time in attending meetings and activities set by the school" and "failure to attend the orientation program or a general assembly for the parents every beginning of the school year" ranked 1.5 with 17 respondents as the highest. This is obvious with parents' attendance during meetings and general assembly. The lowest frequency of 10 with a rank of 10 also being the last is "inability to give emotional and moral support to their children." This could be attributed to the fact that it may not very be visible for teachers to see parents giving emotional and moral support to their children, this is subjective because teachers' basis for the said indicator might be behavior only or anything they think fits the statement.

TABLE VIII: COMMON PROBLEMS AND ISSUES ENCOUNTERED BY THE TEACHERS REGARDING THE INVOLVEMENT OF THE PARENTS IN ENHANCING THE ACADEMIC PERFORMANCE OF THE STUDENTS

\begin{tabular}{|c|c|c|}
\hline Indicators & Frequency & Rank \\
\hline $\begin{array}{l}\text { 1. Inability of parents to give physical time in } \\
\text { attending meetings and activities set by the school. }\end{array}$ & 17 & 1.5 \\
\hline $\begin{array}{l}\text { 2. Failure to attend the orientation program or a } \\
\text { general assembly for the parents every beginning of } \\
\text { the school year. }\end{array}$ & 17 & 1.5 \\
\hline $\begin{array}{l}\text { 3. Lack of time of parents to actively participate in } \\
\text { school activities, outreach programs etc. }\end{array}$ & 15 & 3.5 \\
\hline $\begin{array}{l}\text { 4. Inability of parents to help their children in their } \\
\text { studies. }\end{array}$ & 14 & 5 \\
\hline $\begin{array}{l}\text { 5. Inadequate knowledge of parents about school } \\
\text { policies and regulations. }\end{array}$ & 12 & 8 \\
\hline $\begin{array}{l}\text { 6. Limited financial resources and lack of } \\
\text { transportation. }\end{array}$ & 13 & 6.5 \\
\hline $\begin{array}{l}\text { 7. Inadequate support, encouragement/motivation to } \\
\text { their children to do good in school. }\end{array}$ & 13 & 6.5 \\
\hline $\begin{array}{l}\text { 8. Inability to provide quality time to support their } \\
\text { children in their studies. }\end{array}$ & 11 & 9 \\
\hline $\begin{array}{l}\text { 9. Inability to give emotional and moral support to } \\
\text { their children. }\end{array}$ & 10 & 10 \\
\hline $\begin{array}{l}\text { 10. Lack of close monitoring on the students progress } \\
\text { in school and making way on how the children } \\
\text { would cope their failing grades. }\end{array}$ & 15 & 3.5 \\
\hline
\end{tabular}




\section{CONCLUSION}

It can be safely concluded that the parental involvement strategies affect the academic performance of the students in Mathematics but not to a significant extent. The null hypothesis therefore which states that "the parental involvement strategies of parents did not produce significant effects on the academic performance of students in Mathematics" is sustained.

\section{RECOMMENDATION}

On the basis of the conclusions of this study, the following recommendations were hereby offered: Strengthen the guidance of the teachers to attain the desired proficiency in Mathematics. Establish good rapport with parents and if possible, do home visitation to find out the root of the problem behind the non-attendance of parents during school meetings, orientations, programs and other activities. Employ close monitoring of students' academic performance by giving enrichment activities and remedial classes.

\section{CONFLICT OF INTEREST}

There is no conflict of interest.

\section{AUTHOR CONTRIBUTION}

Dr. Cecilia Junio-Sabio is the lead researcher who wrote the final paper per IJIET standard and that one submitted to the conference in Seoul, Korea.

\section{REFERENCES}

[1] C. Singh, "Race/ethnicity and early mathematics skills: Relations between home, classroom, and athematics achievement," The Journal of Educational Research, vol. 108, pp. 261-277, 2016.

[1] P. Mathipa, "The relationship between parental involvement and adequate yearly progress among urban, suburban, and rural schools,' School Effectiveness and School Improvement, vol. 25, pp. 629-650, 2014.

[2] E. L. R. Abulon and J. D. F. Saquilabon, "Enhancing academic performance through parental involvement strategies," in Proc. 2016 The Normal Lights, pp. 33-49, 2016.

[3] S. A. Crosby, T. Rasinski, N. Padak, and K. Yildirim, "A 3-year study of a school-based parental involvement program in early literacy," The Journal of Educational Research, vol. 108, pp. 165-172, 2012.

[4] A. A. Deci, A Comparative Analysis of the Teacher Competence and Its Effect on Pupil Performance in Upper Primary Schools in Mozambique And Other Sacmeq Countries," University of Pretoria, Pretoria, 2012.

[5] A. Carlos, K. Robinson, and A. Harris. The Broken Compass: Parental Involvement with Children's Education, Cambridge, MA: Harvard University Press, 2014.

[2] F. Wong, "Precocious prosociality: Why do young children help?" Child Development Perspectives, vol. 9, pp. 1-6, 2015.

Copyright (C) 2019 by the authors. This is an open access article distributed under the Creative Commons Attribution License which permits unrestricted use, distribution, and reproduction in any medium, provided the original work is properly cited (CC BY 4.0).

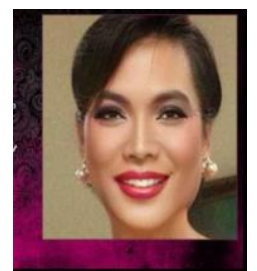

Avelina M. Aquino holds the rank of professor VI; she is also the adviser of Mentors' Publications. She was formerly the supervisor of student teaching in English and formerly the director of the admissions office at the Bulacan State University, City of Malolos. Likewise, she is a part-time professorial lecturer in the graduate school of Don Honorio Ventura Technological State University, Bacolor Pampanga and La Consolacion University-Philippines, City of Malolos.

Dr. Aquino has written 7 Filipino short stories for children in the Philippine Journal of Education (PJE). She has written 5 books produced by Rex Book Store and 13 books produced by Jymzyville Publications. She has presented 11 papers in national and international conventions and has published 3 papers in the national refereed research journals and 3 papers in the international refereed research journals.

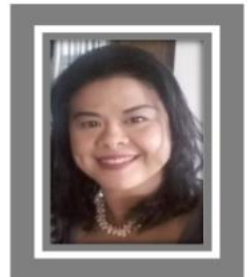

C. J. Sabio was the former vice president for academic affairs and held the rank of SUC vice president IV at the Pamantasan ng Lungsod ng Maynila (University of the City of Manila). She holds professor $\mathrm{V}$ academic rank in the same University. She has previously worked at the commission on higher education (CHED), office of the chairman, office of the president of the Philippines and a GOCC holding various management and executive position. She was the former head of the Research and Industry Engagement Center of the Gulf College based in Muscat Oman which is in collaboration with Staffordshire University, University of Reading and Hull University London, UK. She also teaches in DLSAU and PUP Graduate Schools.

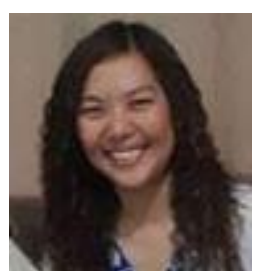

Florinda G. Vigonte is from Tambubong, San Rafael, Bulacan, Philippines 3008. Currently she is pursuing the doctor of philosophy in educational leadership and management with specialization in management research at La Consolacion University, Philippines.

She is an instructor I at Bulacan State University (BulSU), Bustos Campus - Bustos, Bulacan, Philippines. She authored the following books: psychology (Malabon city, Philippines: Jimczyville Publications, 2015); fundamentals of accountancy, business \& management I (Malabon city, Philippines: Jo-Deh Publishing, 2016); and accountancy, business \& management II (Malabon city, Philippines: Jo-Deh Publishing, 2017).

Mrs. Vigonte is the chair for the Accreditation Committee Area V (Research) of the BulSU College of Industrial Technology. Elected and served as Treasurer of the local Faculty Association Union. Recipient of Outstanding Teacher Award of Sanctuario of St. Maria Theresa School.

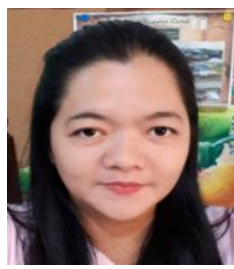

Nerinissa R. De Leon is from Tibagan, Bustos, Bulacan, Philippines. She was born on November 15 1981. She finished the master of arts in educational major in educational management at La Consolacion University, Philippines.

She is a science teacher at Tibagan National High School at Tibagan, Bustos, Bulacan, Philippines. She is forrmer guidance counselor at Angat National High School. She is interested in making researches about teaching and learning. Ms. De Leon is an active member of Bulacan Public School Teachers Association. 